\title{
Aspartic Acid Measurement
}

National Cancer Institute

\section{Source}

National Cancer Institute. Aspartic Acid Measurement. NCI Thesaurus. Code C122097.

The determination of the amount of aspartic acid present in a sample. 